\title{
Effect of the Shot Peening Process on the Corrosion and Oxidation Resistance of AISI430 Stainless Steel
}

\author{
Jefferson da Silva Peltz ${ }^{a}$, Lilian Vanessa Rossa Beltrami ${ }^{a *}$, Sandra Raquel Kunst ${ }^{b}$, \\ Cristiane Brandolt ${ }^{a}$ Célia de Fraga Malfatti ${ }^{a}$
}

\author{
${ }^{a}$ Laboratório de Pesquisa em Corrosão - LAPEC, Universidade Federal do \\ Rio Grande do Sul - UFRGS, Porto Alegre, RS, Brazil \\ ${ }^{b}$ Programa de Pós Graduação em Engenharia de Processos e Tecnologias - PGEPROTEC, \\ Universidade de Caxias do Sul-UCS, Caxias do Sul, RS, Brazil
}

Received: August 13, 2014; Revised: April 28, 2015

\begin{abstract}
Ferritic stainless steels are used in specific applications where corrosion resistance, oxidation resistance and a high mechanical resistance are required. Shot peening is a process applied to add residual compression stresses in metallic surfaces with the intent of improving the material when exposed to corrosion due to stress and fatigue. Some studies about the effect of the shot peening process on the fatigue resistance, bending fatigue behavior, and residual surface stress in the ferritic stainless steels have been performed. However, the effect of the shot peening process on the corrosion and oxidation resistance of the stainless steel is not well known. In this context, the purpose of this study is to evaluate the effect of the shot peening process on these superficial properties of ferritic AISI 430 stainless steel. The obtained results showed that the ferritic AISI430 stainless steel samples treated with shot peening presented a significant modification on the surface morphology and an important decrease of oxidation and corrosion resistance, evidencing that the shot peening process compromises the chemical and physical properties of the surface.
\end{abstract}

Keywords: ferritic stainless steel, shot peening, corrosion, oxidation

\section{Introduction}

Ferritic stainless steels are used in applications where high corrosion and oxidation resistance is required. These types of steel have as characteristics easy processing and good formability combined with a low price, compared to other types of stainless steel ${ }^{1,2}$.

The shot peening process is a surface treatment method that increases the surface hardness of metallic materials by creating a sharp compressive stress due to ball impact on the material surface ${ }^{3-5}$. It is a cold working process where small spheres bombard the surface of the workpiece by means of a jet of compressed air.

During the shot peening each ball impacting on the metallic surface behave as a small hammer, increasing the hardness of the surface, creating a small indentation or semi-sphere. To create these indents the metal surface must undergo a mechanical limit above its yield stress. Due to overlapping of indentations a uniform layer of compressive stress is generated on the metal surface. Shot peening is applied to improve the fatigue resistance of metallic components and can increase lifespan, resistance to alternating loads, and corrosion resistance ${ }^{6-15}$.

However, the shot peening process showed no real improvements in corrosion resistance ${ }^{16}$. Residual stresses are

*e-mail: lvrossa@yahoo.com.br generated by plastic deformation applied to the metal, and these residual stresses remain after removal of the external force ${ }^{17}$ and can be beneficial or detrimental depending on the sign, magnitude and distribution of these stresses ${ }^{18}$. The most common classification of residual stresses refers to the coverage area and can be macroscopic, microscopic and submicroscopic residual stresses. On the other hand, the oxidation resistance of ferritic stainless steel can also be improved by refined microstructure after shot peening. The reason is that with the refined microstructure, the diffusion of chromium ions along the grain boundaries is much quicker than through the grains themselves ${ }^{19}$. This leads to the early formation of the protective chromiumrich oxide layer, which slows down further growth of the iron oxide layer due to its low permeability. Researchers studied the effect of the shot peening process on the fatigue resistance, bending fatigue behavior and residual surface stress in the ferritic stainless steels ${ }^{20-23}$. However, there is not a review of the effect of the shot peening process on the properties of ferritic stainless steel exposed to corrosive and oxidative means.

In this context, the objective of this research was to evaluate the effect of the shot peening process on the superficial properties, such as corrosion and oxidation resistance of AISI430 ferritic stainless steel. 


\section{Experiment}

In this work samples of AISI430 ferritic stainless steel with dimensions of $260 \times 140 \times 1.2 \mathrm{~mm}$ were used. Table 1 shows the chemical composition of AISI430 stainless steel used in this study, according to the specification of the supplier.

Parameters and conditions used in the shot peening process were based on the literature ${ }^{3,11}$, as follows: spheres of ceramic material $\left(\mathrm{SiO}_{2}\right)$ with a nominal diameter of $0.6 \mathrm{~mm}$; jetting angle of approximately $80^{\circ}$ with respect to the base plate; distance of jet appliance of approximately $100 \mathrm{~mm}$; nominal air pressure of 6 bar; blasting time of 40 minutes and flow/mass flow blasting $50 \mathrm{~kg} \cdot \mathrm{min}^{-1}$.

After the shot peening process the stainless steel plate was washed using an ethanol jet and afterwards it was dried with a hot air jet. For the characterization of the steel sheet, after treated with the shot peening process, samples with dimensions of $20 \times 20 \times 1.2 \mathrm{~mm}$ were cut, degreased by immersion into detergent at $70^{\circ} \mathrm{C}$ for $10 \mathrm{~min}$; then washed in ethanol, dried with jet air. These samples were labeled as shot peening samples.

Samples without shot peening process (used as a reference) were cleaned and a part was retained as it was received from the distributor (identified as bare sample) and a part was sanded (identified as sanded sample). The sanding process was performed through the use of sandpapers, respectively $\# 180$, 320, 600 and 1200 . After the sanding process, the samples were washed with ethanol and dried with compressed air. The characterization analyses were performed with 5 samples (five replications) in each category (bare, sanded, shot-peening samples) and the results were calculated from the averages.

The morphological characterization was performed by using a Scanning Electron Microscopy (SEM), with a JEOL-JSM 6510LV equipment, and an acceleration voltage of $20 \mathrm{kV}$. The surface micro-roughness was evaluated in a contact profilometer (PRO500 3D).

The wettability was evaluated by contact angle measurements with the sessile drop method in equipment

Table 1. Chemical composition of AISI430 ferritic stainless steel.

\begin{tabular}{cc}
\hline Element & Mass (\%) \\
\hline $\mathrm{C}$ & 0.05 \\
$\mathrm{Mn}$ & 0.4 \\
$\mathrm{Si}$ & 0.32 \\
$\mathrm{P}$ & 0.034 \\
$\mathrm{~S}$ & 0.0003 \\
$\mathrm{Cr}$ & 16.03 \\
$\mathrm{Ni}$ & 0.26 \\
$\mathrm{Mo}$ & 0.01 \\
$\mathrm{Al}$ & 0.001 \\
$\mathrm{Cu}$ & 0.018 \\
$\mathrm{Co}$ & 0.018 \\
$\mathrm{~V}$ & 0.044 \\
$\mathrm{Nb}$ & 0.02 \\
$\mathrm{Ti}$ & 0.01 \\
$\mathrm{Sn}$ & 0.004 \\
$\mathrm{~N}(\mathrm{ppm})$ & 164 \\
\hline
\end{tabular}

developed by the Laboratory of Corrosion Research (LAPEC) at UFRGS. The contact angle was determined by using image analyses software.

The corrosion performance was evaluated by open circuit potential (Ecorr) monitoring, polarization curves and electrochemical impedance spectroscopy (EIS) measurements in a $0.05 \mathrm{M} \mathrm{NaCl}$ solution. A three-electrode cell was used to perform the analyses, with a platinum wire as a counterelectrode and a saturated calomel electrode (SCE) as the reference electrode. The area of the working electrode was $0.626 \mathrm{~cm}^{2}$. The polarization curves were performed in a potential interval between $200 \mathrm{mV}$ (below OCP - open circuit potential) and $400 \mathrm{mV}$ (above OCP) with a scan rate of $1 \mathrm{mV} \cdot \mathrm{s}^{-1}$. The corrosion rate $\left(\mathrm{i}_{\text {corr }}\right)$, the corrosion potential $\left(\mathrm{E}_{\text {corr }}\right)$ and the polarization resistance $\left(\mathrm{R}_{\mathrm{p}}\right)$ were determined by the taffel extrapolation from the potentiodynamic polarization. The measurements were obtained with the NOVA ${ }^{\circledR}$ software.

For the EIS measurements, the systems were monitored for 96 hours. The amplitude of the EIS perturbation signal was a $10 \mathrm{mV}$ sinusoidal (rms signal) and the frequency range studied was from $100 \mathrm{kHz}$ to $10 \mathrm{mHz}$ using a NOVA ${ }^{\circledR}$ frequency response analyzer and a AUTOLAB PGSTAT 30 potentiostat.

Oxidation tests were conducted in an air atmosphere of $800^{\circ} \mathrm{C}$ for 96 hours, in a muffle (Sanchis). The mass gain of the samples was also monitored.

The phases present after the oxidation of the samples were identified by X-ray diffraction performed on a Philips X-Ray Analytical X'Pert-MPD System equipment, and a PW3040/00 console. The X-ray tube is PW3373/00 with Cu anode from the Laboratory of Ceramic Materials at UFRGS (LACER - UFRGS).

\section{Results and Discussion}

Figure 1 shows the SEM micrographs of the surface samples. It is observed that the Bare sample (Figure 1a) shows small surface irregularities, probably generated in the manufacturing process and handling. Sanded sample (Figure 1b) shows small creasesresulting of the sanding process, while the shot peening sample (Figure 1c) shows that the great deal of cracks and imperfections on the surface. Scratches and features of detached pieces were found all over the sample surface, that is, there are deformed layers near the surface after the shot peening.

The irregularities observed by SEM for the Shot peening sample promote greater surface roughness, as proven from the test results of 3D profilometry shown in Table 2 and Figure 2. This greater roughness is due to plastic deformation generated by the impact of spheres on the metal surface during the shot peening process.

The sanded sample presents twice the roughness of the Bare sample, which was expected due to the process performed on the surface. However, these values are relatively low compared to the shot peening sample, denoting that the sanding process was performed regularly and evenly on the sample surface.

The wettability results (Table 2) show that the three samples present hydrophilic surfaces, with a contact angle lower than $90^{\circ 24]}$. However, the shot peening sample showed a contact angle of $31 \%$ lower compared to the sanded sample 


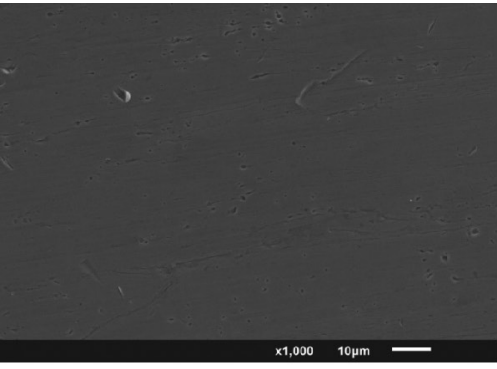

(a)

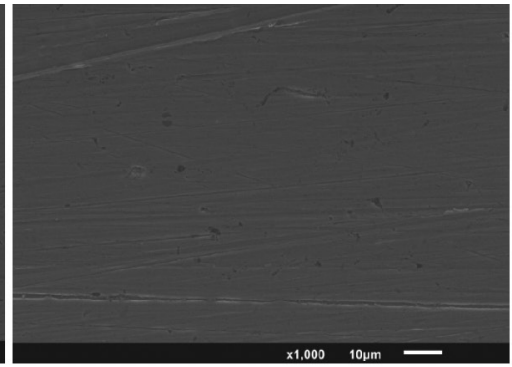

(b)

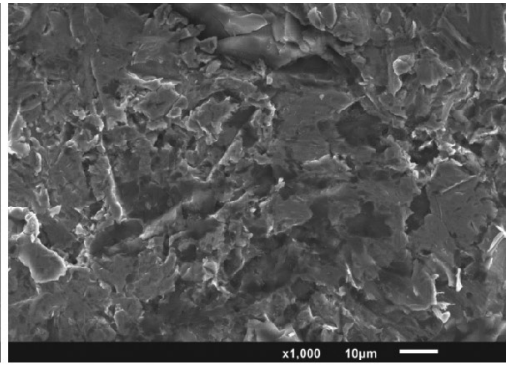

(c)

Figure 1. SEM of the samples: (a) Bare, (b) Sanded and (c) Shot peening.

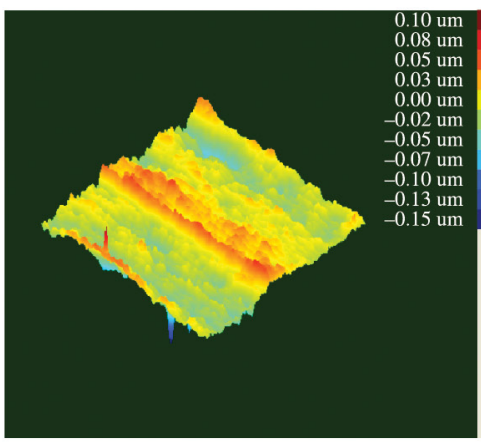

(a)

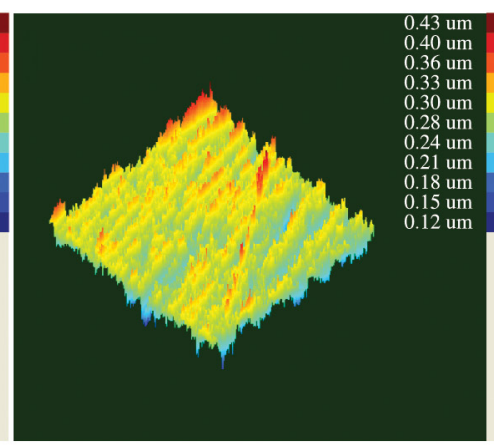

(b)

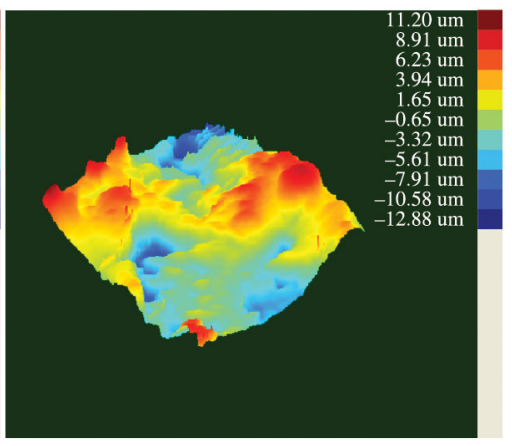

(c)

Figure 2. Images of the surface topography obtained by profilometry for the samples: (a) Bare, (b) Sanded and (c) Shot peening.

Table 2. Results of profilometry and wettability of the samples.

\begin{tabular}{|c|c|c|c|c|}
\hline \multirow[b]{2}{*}{ Sample } & \multicolumn{3}{|c|}{ Roughness } & \multirow{2}{*}{ Contact Angle } \\
\hline & $\mathrm{R}_{\mathrm{a}}(\mu \mathrm{m})$ & $\mathbf{R}_{\mathrm{ms}}(\boldsymbol{\mu m})$ & $\mathbf{R}_{\mathrm{pp}}(\boldsymbol{\mu m})$ & \\
\hline Bare & $0.02 \pm 0.01$ & $0.02 \pm 0.01$ & $0.24 \pm 0.07$ & $74^{\circ} \pm 0.8^{\circ}$ \\
\hline Sanded & $0.03 \pm 0.01$ & $0.04 \pm 0.01$ & $0.41 \pm 0.08$ & $88^{\circ} \pm 0.7^{\circ}$ \\
\hline Shot peening & $3.18 \pm 0.66$ & $3.67 \pm 1.10$ & $22.74 \pm 2.22$ & $69^{\circ} \pm 1.7^{\circ}$ \\
\hline
\end{tabular}

Legend: $\mathrm{R}_{\mathrm{a}}=$ Roughness arithmetic average; $\mathrm{R}_{\mathrm{ms}}=$ Average square roughness; $\mathrm{R}_{\mathrm{pp}}=$ Maximum or peak-to-peak roughness.

and $10 \%$ lower than the bare sample, demonstrating that the shot peening surface has the lowest surface tension.

The increased wettability of the shot peening sample is due to the irregularities and plastic deformations generated by the process, which promoted an increase in surface area (surface roughness) of the sample, making it more susceptible to chemical attack ${ }^{19,25}$

The electrochemical behavior of the samples was analyzed by immersion in a $0.05 \mathrm{M} \mathrm{NaCl}$ solution. The open circuit potential $\left(\mathrm{E}_{\text {ocp }}\right)$ was monitored during the 30 minutes of the immersion (Figure 3a), after polarization curves were performed (Figure $3 b$ ).

The results of the open circuit potential - OCP - (Figure 3a) showed that the sanded sample presented a more active potential than the bare sample. This result was expected considering that the protective layer of stainless steel (chromium oxide) has been removed by the sanding process, what made the surface more susceptible to corrosion.

However, it is observed that the shot peening sample can be considered the most active, as it showed lower values of $\mathrm{E}_{\text {ocp }}$ compared to other studied systems (bare and sanded). This could be associated with some points of hysteresis and thus making the sample more susceptible to pitting corrosion ${ }^{26}$.
Table 3. Results obtained by polarization curves and Tafel extrapolation.

\begin{tabular}{lccc}
\hline \multicolumn{1}{c}{ Sample } & $\mathbf{i}_{\text {corr }}\left[\mathbf{A . c m}{ }^{-2}\right]$ & $\mathbf{E}_{\text {corr }}[\mathbf{m V}]$ & $\mathbf{E}_{\text {pit }}[\mathbf{m V}]$ \\
\hline Bare & $2.0 \times 10^{-8}$ & -140 & 300 \\
Sanded & $6.5 \times 10^{-8}$ & -150 & 350 \\
Shot Peening & $2.5 \times 10^{-7}$ & -250 & 290 \\
\hline
\end{tabular}

The corrosion current density values $\left(i_{\text {corr }}\right)$ of the corrosion potential $\left(\mathrm{E}_{\text {corr }}\right)$ and pitting corrosion potential $\left(\mathrm{E}_{\mathrm{pit}}\right)$ were obtained by analyzing the polarization curves (Figure 3b) and they are shown in Table 3. It is observed that the shot peening process significantly affects the sample surface and reduces the corrosion resistance of the sample. This behavior is confirmed by increased values of $i_{\text {corr }}$ and decreased values of $\mathrm{E}_{\text {corr }}$ and of $\mathrm{E}_{\mathrm{pit}}{ }^{[27]}$. The current density $\left(i_{\text {corr }}\right)$ is directly related to the corrosion rate, consequently, reflects on the intensity of the constant process of corrosion in specific electrolytes ${ }^{28}$.

However, the shot peening sample presented higher values of $i_{\text {corr }}$ when compared to other samples. The lower corrosion resistance of the shot peening sample is attributed to increased surface energy and the residual stresses after the shot peening process, generating more active surfaces ${ }^{28}$. 
These results are in line with the results obtained in the wettability test, because the smaller the contact angle the greater the surface wettability and thus the greater contact of the surface with the medium is, facilitating the chemical and electrochemical reactions on the surface and therefrom decreasing the corrosion resistance ${ }^{29}$.

Figure 4 shows images obtained by the optical micrograph of the surface of the test samples after potentiodynamic polarization. The presence of pits was observed in the bare sample and in the sanded sample, whereas in the shot peening sample it was not possible to observe the localized corrosion. As observed in Figure 1c, the sample shot peening features lots of cracks resulting from the blasting process. Therefore, it is believed that corrosion occurred preferentially within these cracks and for this reason, it is not possible to observe the corrosion spots on the surface (Figure 4c).

The sanded sample showed a passivity phenomenon at initial measurements of polarization curves, which then went on to present localized corrosion on the surface in the form of pits.

The electrochemical impedance spectroscopy (EIS) tests were performed (Figure 5). Figure 5 shows the Bode diagrams obtained by electrochemical impedance for the bare, sanded and shot peening samples performed in 24 and 96 hours in a $0.05 \mathrm{M} \mathrm{NaCl}$ solution. At 24 and 96 hours of immersion the diagrams showed no significant changes. However, the impedance of the Shot peening sample is lower than the other samples. This could be explained due to the increased roughness of the sample surface. This surface after the shot peening process is attacked faster due to increased surface energy and residual stresses after the shot peening process, which leads to a more active surface and thus more susceptible to chloride ions on the metal surface. These results correspond with the results obtained by the polarization test (Figure 3 ).

Figure 6 shows the image obtained by SEM micrograph of the samples surface after the EIS test. An increase in irregularities in the surfaces of the samples after EIS test is observed, when compared to the samples before the EIS test (Figure 1).

Figure 7 shows the relationship between the weight gains with the oxidation time for the studied samples. With an increase in the exposure time to high temperatures, all samples showed an increase in their weight. Throughout the oxidation test the shot peening sample showed the highest values of weight gain in relation to others samples. The three systems showed a tendency of parabolic oxidation kinetics. This oxidation kinetics is typical for ferritic steels ${ }^{30}$. The oxide scale growth rate is calculated by Equation 1, where $M$ is the sample mass gain, $A$ is the sample surface area, $t$ is the oxidation time and $\mathrm{Kp}$ is the parabolic rate constant. The result of parabolic rate constant (Kp) (Table 4) of the bare sample is consistent with values presented in studies in the literature ${ }^{31-33}$. It is observed that the Kp results (Table 4) are similar for all the samples, which demonstrate that the formation of oxide was not influenced by the difference in surface samples.

$(\Delta \mathrm{M} / \mathrm{A})^{2}=\mathrm{Kp} . \mathrm{t}$

Figure 8 shows the image of the surface morphology obtained by SEM of the samples surface after oxidation for 96 hours at $800^{\circ} \mathrm{C}$. After the oxidation test, it was observed that the surfaces of the bare and sanded samples showed a formation of the oxide layer completely covering the surface.

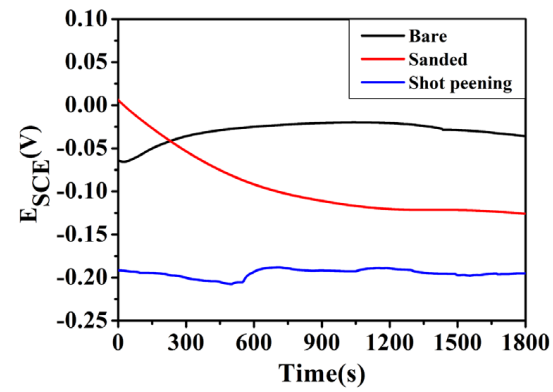

(a)

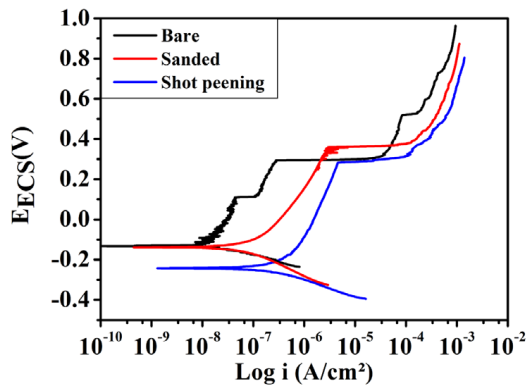

(b)

Figure 3. Open circuit potential (OCP) (a) and polarization curves (b) of the samples.

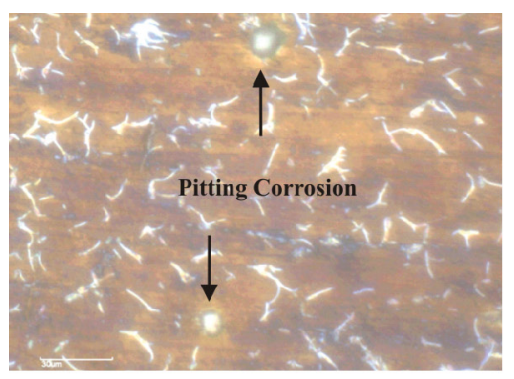

(a)

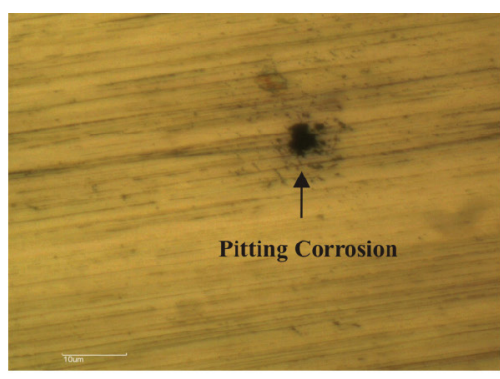

(b)

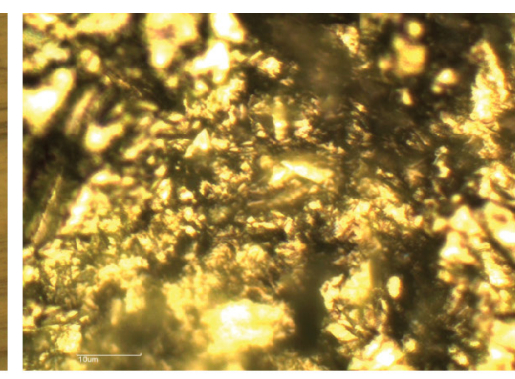

(c)

Figure 4. Optical micrograph of the samples surface: (a) Bare, (b) Sanded and (c) Shot peening, after potentiodynamic polarization. 

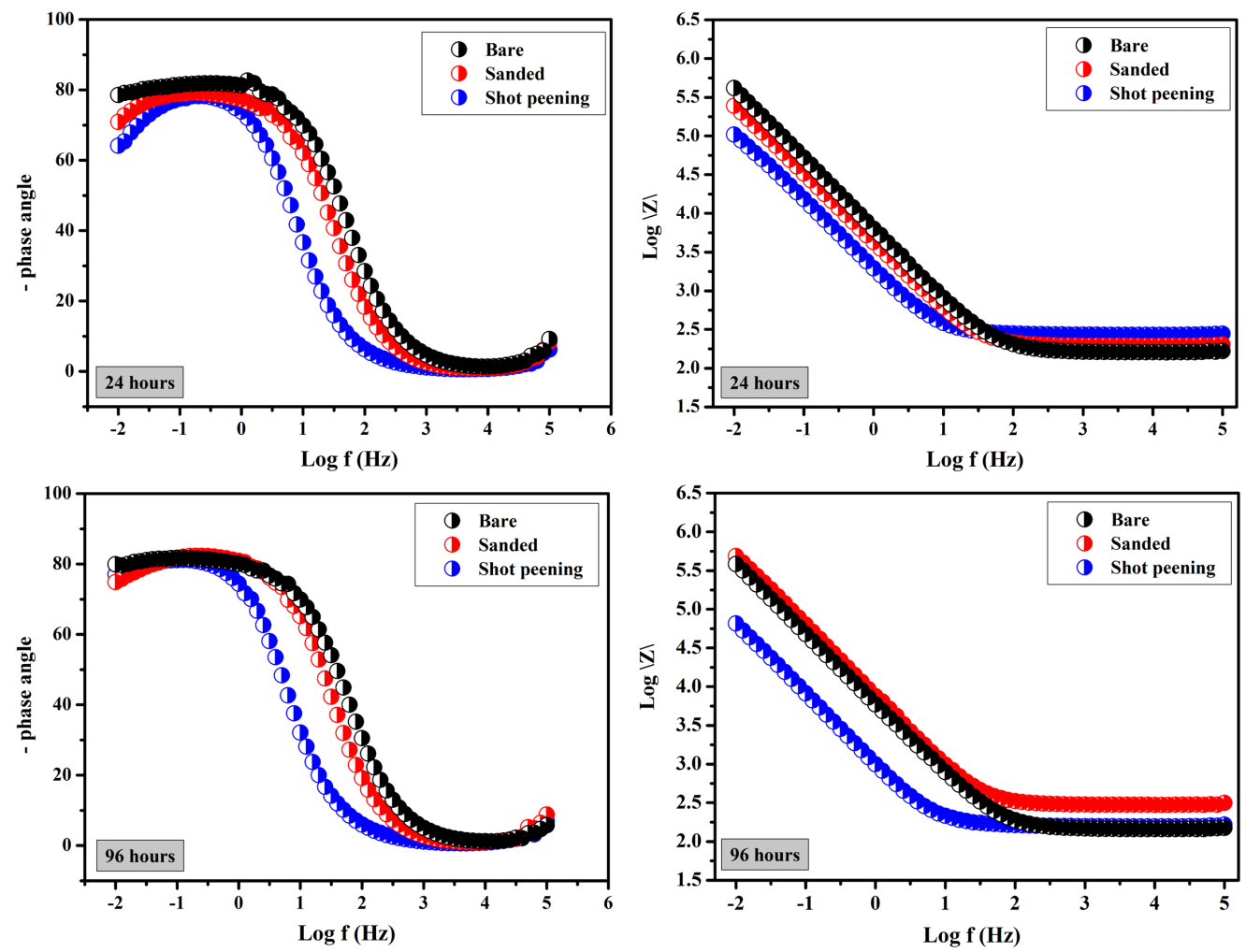

Figure 5. Bode diagrams obtained from the samples in $0.05 \mathrm{M} \mathrm{NaCl}$ solution.

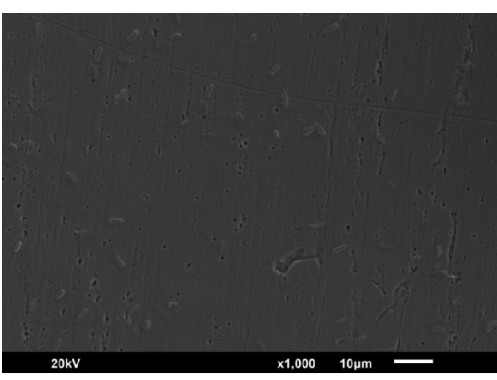

(a)

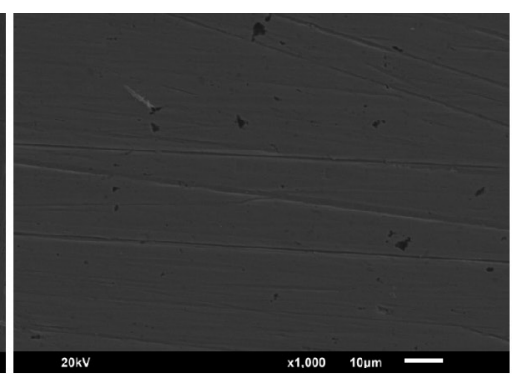

(b)

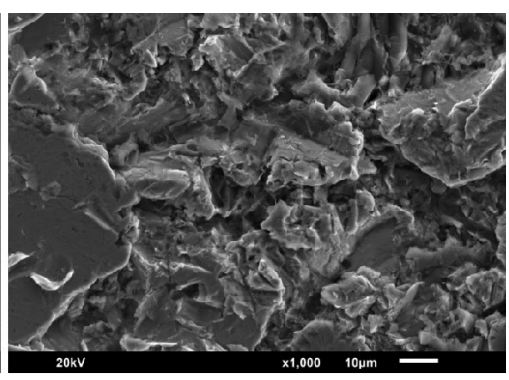

(c)

Figure 6. SEM micrographs of the: (a) Bare, (b) Sanded and (c) Shot peening samples, after the EIS test.

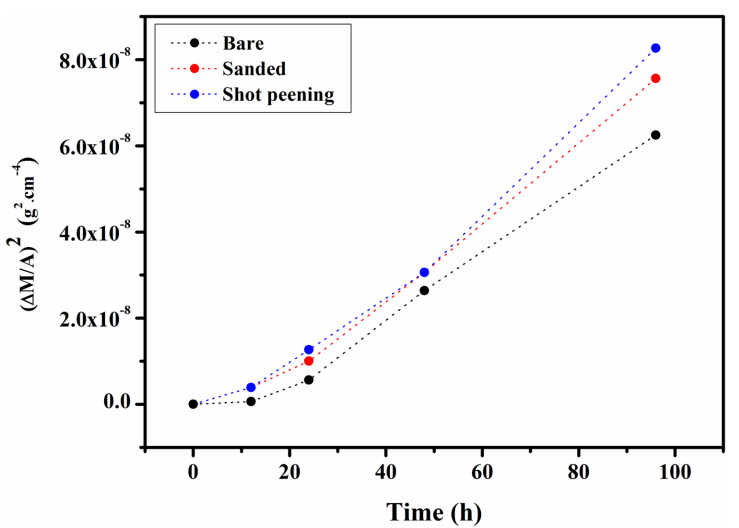

Figure 7. Oxidation test at temperature of $800^{\circ} \mathrm{C}$.
The observed shot peening sample showed that the oxide layer covered all the surface irregularities, forming small plaques of oxide over the surface. The fragile surface of the sample Shot peening caused increased formation and growth of oxide. Due the greater volume, the oxide tends to flake, forming small oxide plaques on the sample surface. The presence of plaques was observed in situations where oxidation is more intense and is associated with greater weight gain.

Figure 9 shows the XRD of the studied samples. The presence of chromium oxide $\left(\mathrm{Cr}_{2} \mathrm{O}_{3}\right)$ was observed in all samples, which was expected, since the presence of this oxide is usual in stainless steels when exposed to high temperatures ${ }^{34}$. 


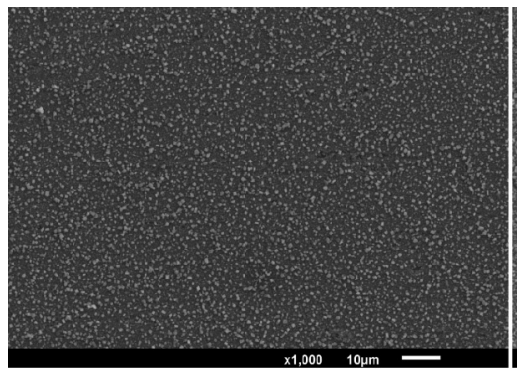

(a)

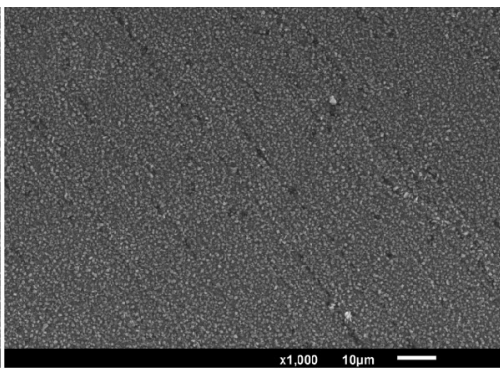

(b)

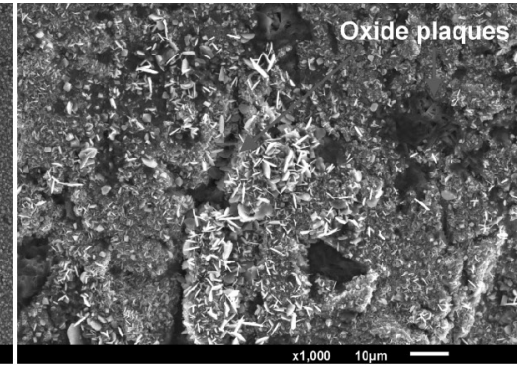

(c)

Figure 8. SEM micrographs of the: (a) bare, (b) sanded and (c) shot peening samples, after an oxidation test of 96 hours at $800^{\circ} \mathrm{C}$.
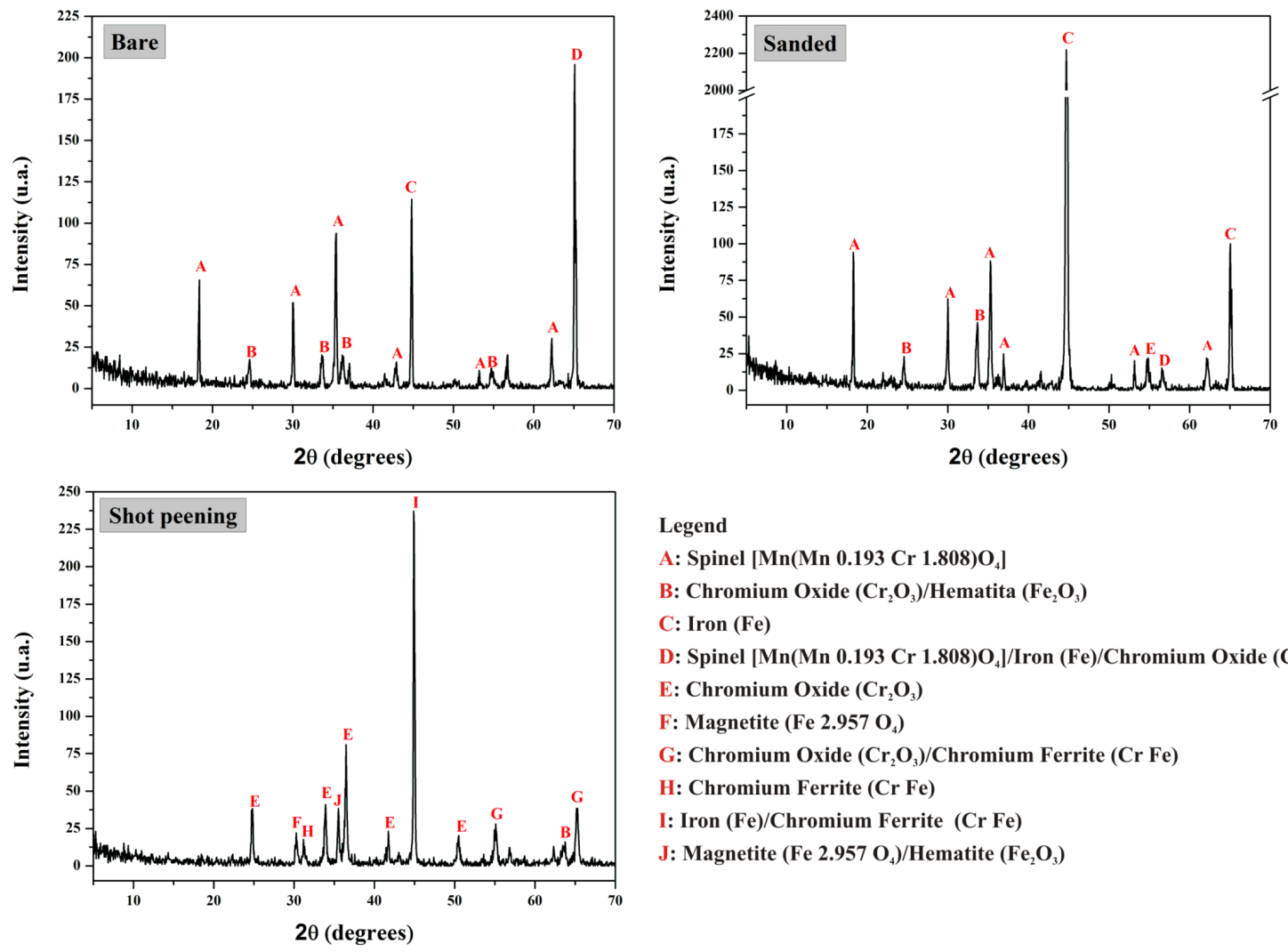

Legend

A: Spinel [Mn(Mn 0.193 Cr 1.808) $\left.\mathrm{O}_{4}\right]$

B: Chromium Oxide $\left(\mathrm{Cr}_{2} \mathrm{O}_{3}\right) / \mathrm{Hematita}\left(\mathrm{Fe}_{2} \mathrm{O}_{3}\right)$

$\mathrm{C}$ : Iron (Fe)

D: Spinel [Mn(Mn 0.193 Cr 1.808) $\left.\mathrm{O}_{4}\right] / /$ ron (Fe)/Chromium Oxide $\left(\mathrm{Cr}_{2} \mathrm{O}_{3}\right)$

E: Chromium Oxide $\left(\mathrm{Cr}_{2} \mathrm{O}_{3}\right)$

F: Magnetite ( $\left.\mathrm{Fe} 2.957 \mathrm{O}_{4}\right)$

G: Chromium Oxide $\left(\mathrm{Cr}_{2} \mathrm{O}_{3}\right) /$ Chromium Ferrite ( $\left.\mathrm{Cr} \mathrm{Fe}\right)$

$\mathrm{H}$ : Chromium Ferrite (Cr Fe)

I: Iron (Fe)/Chromium Ferrite (Cr Fe)

J: Magnetite (Fe $\left.2.957 \mathrm{O}_{4}\right) / \mathrm{Hematite}\left(\mathrm{Fe}_{2} \mathrm{O}_{3}\right)$

Figure 9. Diffractograms of the samples after the oxidation test.

Table 4. Results of parabolic rate constant (Kp) by oxidation test.

\begin{tabular}{cc}
\hline Sample & $\mathbf{K p}\left(\mathbf{g}^{2} \cdot \mathbf{c m}^{-4} \cdot \mathbf{s}^{-1}\right)$ \\
\hline Bare & $6.92 \times 10^{-13}$ \\
Sanded & $2.26 \times 10^{-13}$ \\
Shot peening & $2.45 \times 10^{-13}$ \\
\hline
\end{tabular}

The formation of spinels, mixed oxides of the manganese and chromium in the bare sample and sanded sample has been observed. Huntz et al. ${ }^{35}$ observed the presence of these same mentioned phases when AISI430 stainless steel was exposed to high temperatures.

In the shot peening sample the formation of these mixed oxides was not observed; however, the presence of magnetite and the presence of rich chromium phases was observed, such as ferrite chromium and chromium oxide. The formation of chromium oxide might happen due to the effect of the oxidation temperature, which is higher than the recrystallization temperature. After the formation of the oxide film on the surface, deformed grains begin to undergo recrystallization which results in a larger number of grain boundaries. These grain boundaries favor the formation of oxides and avoid the solubilization of chrome on the surface. Therefore, it was expected that a denser and more protective oxide would be formed on the deformed surface of the shot peening sample ${ }^{2,36}$. However, this phenomenon did not cause the decrease of the oxidation (rust growth) for the sample treated with the shot peening process in this present study. 


\section{Conclusions}

From the obtained results in the studied conditions, it can be concluded that the shot peening surface treatment significantly alters the surface morphology of the samples of AISI430 stainless steel, by adding irregularities generated by the permanent cold deformations, resulting from the impact of the spheres. These surface irregularities generated by the shot peening process cause a significant increase in surface roughness and consequently an increase in the contact area with the medium, which should have contributed to the decrease in corrosion resistance and oxidation resistance.

Besides, the samples of AISI430 stainless steel treated with shot peening showed a more hydrophilic behavior, compared with the others samples, which contributes to the increase of the reactive surface in relation to the other samples.

Considering the microscopic analysis of samples after a potentiodynamic polarization test, it was not possible to observe the presence of pits in the sample treated with shot peening due to its high surface roughness. On the other hand, for the bare sample and sanded sample the presence of pitting was observed.

\section{References}

1. Ebrahimifar $\mathrm{H}$ and Zandrahimi M. Oxidation and electrical behavior of AISI 430 coated with cobalt spinels for SOFC interconnect applications. Surface and Coatings Technology. 2011; 206(1):75-81. http://dx.doi.org/10.1016/j.surfcoat.2011.06.046.

2. Cooper L, Benhaddad S, Wood A and Ivey DG. The effect of surface treatment on the oxidation of ferritic stainless steels used for solid oxide fuel cell interconnects. Journal of Power Sources. 2008; 184(1):220-228. http://dx.doi.org/10.1016/j. jpowsour.2008.06.010.

3. Hashemi B, Rezaee Yazdi MR and Azar V. The wear and corrosion resistance of shot peened-nitrided 316L austenitic stainless steel. Materials \& Design. 2011; 32(6):3287-3292. http://dx.doi.org/10.1016/j.matdes.2011.02.037.

4. Nascimento MP, Torres MAS, Souza RC and Voorwald HJC. Effect of a shot peening pre treatment on the fatigue behaviour of hard chromium on electroless nickel interlayer coated AISI 4340 aeronautical steel. Materials Research. 2002; 5(2):95-100. http://dx.doi.org/10.1590/S1516-14392002000200002.

5. Costa MYP, Voorwald HJC, Pigatin WL, Guimarães VA and Cioffi MOH. Evaluation of shot peening on the fatigue strength of anodized Ti-6Al-4V alloy. Materials Research. 2006; 9(1):107109. http://dx.doi.org/10.1590/S1516-14392006000100020.

6. Champaigne J. Shot Peening Process Variables. In: The Eleventh International Conference on Shot Peening. 2011; South Bend, USA. South Bend: Electronics Incorporated Mishawaka; 2011. p. 21-27.

7. Chen G, Jiao Y, Tian T, Zhang X, Li Z and Zhou W. Effect of wet shot peening on $\mathrm{Ti}-6 \mathrm{Al}-4 \mathrm{~V}$ alloy treated by ceramic beads. Transactions of Nonferrous Metals Society of China. 2014; 24(3):690-696. http://dx.doi.org/10.1016/S1003-6326(14)631125.

8. Fragoudakis R, Saigal A, Savaidis G, Malikoutsakis M, Bazios I, Savaidis A, et al. Fatigue assessment and failure analysis of shot-peened leaf springs. Fatigue and Fracture of Engineering Materials and Structures. 2013; 36(2):92-101. http://dx.doi. org/10.1111/j.1460-2695.2011.01661.x.
The shot peening sample presented the lowest oxidation resistance compared with the other samples and the growth behavior showed a tendency to parabolic profile. After the oxidation test, on the shot peening sample surface the presence of a chromium oxide was observed, and rich phases were observed on the bare and sanded samples. The Shot peening sample did not present the formation of spinels or mixed oxides of the manganese and chromium.

From the results which were obtained it was possible to observe that the shot peening process significantly altered the surface morphology, reducing the oxidation resistance and the corrosion resistance of the AISI 430 stainless steel samples.

\section{Acknowledgements}

The authors would like to acknowledge the support from Imer Metallurgical Company and the financial support from CAPES (the Brazilian Government Agency for the Development of Human Resources) and CNPq (the Brazilian National Council for Scientific and Technological Development).

9. Olmi G and Freddi A. A new method for modelling the support effect under rotating bending fatigue: application to Ti-6Al-4V alloy, with and without shot peening. Fatigue and Fracture of Engineering Materials and Structures. 2013; 36(10):981-993. http://dx.doi.org/10.1111/ffe.12051.

10. Olmi G, Comandini M and Freddi A. Fatigue on shot-peened gears: experimentation, simulation and sensitivity analyses. Strain. 2010; 46(4):382-395. http://dx.doi.org/10.1111/j.14751305.2009.00685.x.

11. Lee H, Kim D, Jung J, Pyoun Y and Shin K. Influence of peening on the corrosion properties of AISI 304 stainless steel. Corrosion Science. 2009; 51(12):2826-2830. http://dx.doi.org/10.1016/j. corsci.2009.08.008.

12. Guagliano M and Vergani L. An approach for prediction of fatigue strength of shot peened components. Engineering Fracture Mechanics. 2004; 71(4-6):501-512. http://dx.doi. org/10.1016/S0013-7944(03)00017-1.

13. Benedetti M, Bortolamedi T, Fontanari V and Frendo F. Bending fatigue behaviour of differently shot peened Al 6082 T5 alloy. International Journal of Fatigue. 2004; 26(8):889-897. http:// dx.doi.org/10.1016/j.ijfatigue.2003.12.003.

14. Shaw BA, Aylott C, O'Hara P and Brimble K. The role of residual stress on the fatigue strength of high performance gearing. International Journal of Fatigue. 2003; 25(9-11):1279-1283. http://dx.doi.org/10.1016/j.ijfatigue.2003.08.014.

15. Benedetti M, Fontanari V, Höhn B-R, Oster P and Tobie $\mathrm{T}$. Influence of shot peening on bending tooth fatigue limit of case hardened gears. International Journal of Fatigue. 2002; 24(11):1127-1136. http://dx.doi.org/10.1016/S01421123(02)00034-8.

16. Yan B-H, Tzeng H-J, Yuan Huang F, Lin Y-C and Chow H-M. Chow. Finishing effects of spiral polishing method on micro lapping surface. International Journal of Machine Tools \& Manufacture. 2007; 47(6):920-926. http://dx.doi.org/10.1016/j. ijmachtools.2006.07.009.

17. Martins COD, Strohaecker TR, Rocha AS and Hirsch TK. Comparação entre técnicas de análise de tensões residuais 
em anéis de rolamento do aço ABNT 52100. Revista Matéria. 2004; 9(1):23-31.

18. Xiang ZD and Datta PK. Shot peening effect on aluminide diffusion coating formation on alloy steels at low temperatures. Scripta Materialia. 2006; 55(12):1151-1154. http://dx.doi. org/10.1016/j.scriptamat.2006.08.016.

19. Peltz JS, Antonini LM, Kunst SR, Ludwig GA, Fuhr LT and Malfatti CF. Effect of application of the shot peening process in the corrosion resistance of the AISI 430 ferritic stainless steel. Materials Science Forum. 2014; 775:365-369.

20. Takahashi S, Hashimoto M and Hirose Y. An X-Ray study of shot peening material during fatigue. JCPDS-International Centre for Diffraction Data, Advances in X-ray Analysis. 2000; 43:117-122.

21. Soady KA, Mellor BG, Shackleton J, Morris A and Reed PAS. The effect of shot peening on notched low cycle fatigue. Materials Science and Engineering A. 2011; 528(29-30):85798588. http://dx.doi.org/10.1016/j.msea.2011.08.003.

22. Hussain J, Ibrahim YK and Murdhi SS. Effect of shot peening time on fatigue properties of stainless steel shaft turbine. Journal of Engineering and Development. 2012; 16(4):411-424.

23. Zhan K, Jiang CH and Ji V. Effect of prestress state on surface layer characteristic of S30432 austenitic stainless steel in shot peening process. Materials \& Design. 2012; 42:89-93. http:// dx.doi.org/10.1016/j.matdes.2012.05.053.

24. Wu S. Polymer interface and adhesion. New York: CRC Press; $1982.630 \mathrm{p}$.

25. Wenzel RN. Resistance of solid surfaces to wetting by water. Industrial \& Engineering Chemistry. 1936; 28(8):988-994. http://dx.doi.org/10.1021/ie50320a024.

26. Azar V, Hashemi B and Rezaee Yazdi MR. The effect of shot peening on fatigue and corrosion behavior of $316 \mathrm{~L}$ stainless steel in Ringer's solution. Surface and Coatings Technology. 2010; 204(21-22):3546-3551. http://dx.doi.org/10.1016/j. surfcoat.2010.04.015.

27. Kim KM, Park JH, Kim HS, Kim JH, Lee YY and Kim KY. Effect of plastic deformation on the corrosion resistance of ferritic stainless steel as a bipolar plate for polymer electrolyte membrane fuel cells. International Journal of Hydrogen
Energy. 2012; 37(10):8459-8464. http://dx.doi.org/10.1016/j. ijhydene.2012.02.127.

28. Mhaede M, Pastorek F and Hadzima B. Influence of shot peening on corrosion properties of biocompatible magnesium alloy AZ31 coated by dicalcium phosphate dihydrate (DCPD). Materials Science \& Engineering. C, Materials for Biological Applications. 2014; 39:330-335. http://dx.doi.org/10.1016/j. msec.2014.03.023. PMid:24863232

29. Totten GE, Howes M and Inoue T. Handbook of residual stress and deformation of steel. Ohio: ASM International; 2002. 499 p.

30. Birks N, Meier GH and Pettit FS. Introduction to the high temperature oxidation of metals. Cambridge: Cambridge University Press; 2006. http://dx.doi.org/10.1017/CBO9781139163903.

31. Huntz AM, Reckmann A, Haut C, Sévérac C, Herbst M, Resende FCT, et al. Oxidation of AISI 304 and AISI 439 stainless steels. Materials Science and Engineering A. 2007; 447(1-2):266-276. http://dx.doi.org/10.1016/j.msea.2006.10.022.

32. Salgado MF, Sabioni ACS, Huntz A-M and Rossi ÉH. High temperature oxidation behavior of the AISI 430A and AISI 430E stainless steels in $\mathrm{Ar} / \mathrm{H}_{2} / \mathrm{H}_{2} \mathrm{O}$ atmosphere. Materials Research. 2008; 11(2):227-232. http://dx.doi.org/10.1590/ S1516-14392008000200020.

33. Korb M, Savaris ID, Feistauer EE, Barreto LS, Sousa VC, Müller IL, et al. $\mathrm{La} 0.6 \mathrm{Sr} 0.4 \mathrm{CoO} 3$ coating on AISI 430 ferritic stainless steel for application in ITSOFC interconnects. Renewable Energy and Power Quality Journal. 2012; 10:521.

34. Castro GM. Estudo da oxidação a quente no aço inoxidável ferrítico ABNT 430. [Dissertação]. Belo Horizonte: Universidade Federal de Minas Gerais; 2005.

35. Huntz AM, Reckmann A, Haut C, Severac C, Herbst M, Resende FCT, et al. Oxidation of AISI 304 and AISI 439 stainless steels. Materials Science and Engineering A. 2007; 447(1-2):266-276. http://dx.doi.org/10.1016/j.msea.2006.10.022.

36. Shaigan N, Qui W, Ivey DG and Chen W. A review of recent progress in coatings, surface modifications and alloy developments for solid oxide fuel cell ferritic stainless steel interconnects. Journal of Power Sources. 2010; 195(6):1529-1542. http:// dx.doi.org/10.1016/j.jpowsour.2009.09.069. 